\title{
Article \\ Socially-Oriented Approach to Financial Risk Management as the Basis of Support for the SDGs in Entrepreneurship
}

\author{
Anna N. Zhilkina ${ }^{1}$, Marina V. Karp ${ }^{2}$, Anna V. Bodiako ${ }^{3}$, Samal M. Smagulova ${ }^{4}$, Tatiana M. Rogulenko ${ }^{2, *}$ and \\ Svetlana V. Ponomareva ${ }^{5}$
}

\section{check for} updates

Citation: Zhilkina, Anna N., Marina V. Karp, Anna V. Bodiako, Samal M. Smagulova, Tatiana M. Rogulenko, and Svetlana V. Ponomareva. 2022. Socially-Oriented Approach to Financial Risk Management as the Basis of Support for the SDGs in Entrepreneurship. Risks 10: 42. https://doi.org/10.3390/ risks10020042

Academic Editor: Elena Popkova

Received: 28 December 2021

Accepted: 7 February 2022

Published: 16 February 2022

Publisher's Note: MDPI stays neutral with regard to jurisdictional claims in published maps and institutional affiliations.

Copyright: (c) 2022 by the authors. Licensee MDPI, Basel, Switzerland. This article is an open access article distributed under the terms and conditions of the Creative Commons Attribution (CC BY) license (https:// creativecommons.org/licenses/by/ $4.0 /)$.
1 Department of Finance and Credit, State University of Management, 99 Ryazansky Ave., 109542 Moscow, Russia; an_zhilkina@guu.ru

2 Department of Accounting, Auditing and Taxation, State University of Management, 99 Ryazansky Ave., 109542 Moscow, Russia; mv_karp@guu.ru

3 Department of Audit and Corporate Reporting at the Faculty of Taxes, Audit and Business Analysis, Financial University under the Government of the Russian Federation, 125167 Moscow, Russia; anna.bodyako@inbox.ru

4 Department of World Economy and International Economic Relations, State University of Management, 99 Ryazansky Ave., 109542 Moscow, Russia; sm_smagulova@guu.ru

5 Department Audit and Internal Control, Saint Petersburg State University of Economics, 191023 Saint Petersburg, Russia; ponsvetlana@mail.ru

* Correspondence: tm_rogulenko@guu.ru

\begin{abstract}
This paper demonstrates that the level of financial risks and the impact of the COVID19 pandemic and crisis on them are high. The existing approach to financial risk management is not very effective and does not allow coping with financial risks in entrepreneurship, not even in a certain category of countries. As a prospective alternative, we offer a new socially-oriented approach. The theoretical value of the paper lies in the offering and scientific substantiation of a new hypothesis: that the SDGs could and should be constantly supported by business in their financial risk management with the help of the socially-oriented approach, which is available and expedient for use under the conditions of economic crisis. The practical value of the received results is as follows: the developed new (alternative) socially-oriented approach to financial risk management in entrepreneurship allows increasing the effectiveness of financial risk management in entrepreneurship and raising its robustness against the current COVID-19 crisis. The social importance of the obtained conclusions and results is that the developed approach allows for and stimulates continuous support for the SDGs in entrepreneurship.
\end{abstract}

Keywords: socially-oriented approach; financial risk management; support for the SDGs; entrepreneurship

\section{Introduction}

The Sustainable Development Goals (SDGs) are supported widely and actively in entrepreneurship around the world. This is reflected in the high and annually growing level of corporate social responsibility. The problem is that, first, this responsibility is not connected to finance on the whole and to financial risk management in particular (Ma and Ren 2021). Corporate social responsibility is a tool of achieving the growth of labor efficiency (through increasing employee loyalty to the company) and stimulating sales (through improving social and ecological properties of products and an increase in consumer loyalty).

Second, an economic crisis is considered to be a phase of the economic cycle, which is unfavorable for manifesting corporate social responsibility. Though many companies continue to manifest high corporate social responsibility under the conditions of crisis, these are mainly large business structures that consider measures connected to the implementation of this responsibility unprofitable (do not strive to gain advantages from it), since under the conditions of crisis: (1) unemployment grows, and employees hold onto their jobs, 
regardless of loyalty to the company and (2) consumers are not interested and/or cannot pay an increased price for the improved social or ecological properties of products. That is, under the conditions of crisis, corporate social responsibility is associated with non-profit activities and is considered to be exclusive (not widely accessible) (Torrès et al. 2021).

For sustainable development, temporary refusal of support for the SDGs under the conditions of crisis could destroy all previous progress and mean the return to the initial (unsustainable) state of society, business, and economy. Responsible businesses cannot quickly adapt to the reduction of the level of corporate social responsibility and experience the imbalance of corporate culture and crisis management. In addition to this, competitive advantages in loyalty are lost: business suffers image losses and loses its social capita and employee loyalty (best personnel, increased productiveness, and unique corporate knowledge) and consumer loyalty (stable and high demand and reduced price-demand elasticity) (Rouleau et al. 2021).

This problem is caused by the existing business-oriented approach to financial risk management in entrepreneurship. The essence of this approach is as follows: financial interests of business (reduction of financial risks, achievement of the goal of profit maximization) in it are opposed to the non-financial interests of society (including consumers and employees). Due to this, entrepreneurship's support for the SDGs is treated as contradicting its financial interests (increasing financial risks, hindering the fight against the risks, and reducing profit), especially under the conditions of economic crisis.

However, according to the international experience under the conditions of the 2008 recession (Çağll and Turkmen 2017; Kabonga 2020) and under the conditions of the recession caused by the COVID-19 pandemic and the 2020-2021 lockdown (Galindo-Martín et al. 2021; Liu and Froese 2020), refusal of corporate social responsibility does not guarantee the success of crisis management, while companies that constantly support the SDGs are often less susceptible to the negative impact of a crisis and take less time to recover after it. Based on the above, the following research question is posed in this paper: Can the SDGs be supported by businesses during their financial risk management? How could the described approach be used to achieve this? Is this approach available (expedient to use) under the conditions of crisis?

This paper's goal is to develop a new (alternative) socially-oriented approach to financial risk management in entrepreneurship and prove its advantages from the positions of financial risk management and expedience of its use under the conditions of economic crisis. To achieve this goal, the three following topics are addressed in this paper:

- Determining the level of financial risks and the impact of the COVID-19 pandemic and crisis on them;

- Proposing a socially-oriented approach to financial risk management in entrepreneurship and outlining its specifics and advantages (compared to the business-oriented approach);

- Assessing the applicability of the socially-oriented approach to financial risk management in entrepreneurship under the conditions of crisis.

\section{Literature Review}

This paper uses the existing literature on the topic of financial risk management. In the work of Saha and Dutta (2022), the quality of management that is combined with inclusive financing and stability has a decisive role in the success of financial risk management of the business. Ayadi et al. (2022) note a large currency risk in business cycles. Shahzad et al. (2022) substantiate the intermediary role of formalization of risk management methods to counter the perceived risk of business and establish the effectiveness of an organization. 
Based on the data of the Japanese Real Estate Investment Trust Market, Mori et al. (2022) prove the necessity for risk sharing of business groups. Weber and Müßig (2022) substantiate the important effect of business strategy on risk disclosure and the effectiveness of financial risk management. Singh (2022) proves that business risk resilience increases with the help of risk management infrastructure.

The influence of economic crises that preceded the COVID-19 crisis on financial risk management has also been thoroughly studied in the publications of Aloui et al. (2019), Barontini and Taglialatela (2021), Bratis et al. (2020), Chaivisuttangkun and Jiraporn (2021), $\mathrm{Hu}$ (2020), Lippi and Rossi (2020), and Machokoto et al. (2021).

Corporate social responsibility, as a mechanism of the support of the SDGs in business, was considered in the works of Pérez et al. (2020), Shayan et al. (2022), Sinha et al. (2021), Sinkovics et al. (2021), Waheed and Zhang (2022), and Wentzel et al. (2022). Corporate social responsibility, as a mechanism of the support of the SDGs in business and the core of the proposed socially-oriented approach to financial risk management in business, has been studied from the positions of its contribution to firm value in the works of Berkman et al. (2021), Kharlanov et al. (2022), Popkova and Sergi (2021), and Vagin et al. (2022).

Servaes and Tamayo (2013) show that corporate social responsibility and firm value have a positive connection in the case of companies with high customer awareness. Harjoto and Laksmana (2018) write that a stronger manifestation of CSR is associated with smaller deviations from the optimal level of risk adoption. Arslan-Ayaydin and Thewissen (2016) state that energy sector companies with good environmental performance have better financial results compared to energy sector companies with bad environmental performance.

Despite the significant contribution of corporate social responsibility to the financial risk management of the business, the works of Bae et al. (2021), Havlinova and Kukacka (2021), and Zhang et al. (2022) note that the level of this responsibility is reduced during crises. This is treated by Liang et al. (2022), Lopata and Rogatka (2021), and Magrizos et al. (2021) as a normal reaction of business to the crisis-it is considered that the contribution of corporate social responsibility to the financial risk management of business amid a crisis is reduced (its manifestation is weak).

The theoretical framework of this paper is, first, based on the theory of corporate social responsibility. This theory notes an important contribution of corporate social responsibility to support the SDGs in entrepreneurship, which is described in the works of He et al. (2021), Khan et al. (2021), Popkova and Sergi (2021), and Yankovskaya et al. (2021).

Second, it considers the theory of financial risk management in entrepreneurship. This theory suggests a business-oriented approach to financial risk management in entrepreneurship. The essence of the existing approach consists in treating financial risks as a critical threat to business and in striving for their reduction, regardless of other risks. This is noted in the works of Jiang and Feng (2021), Kruger et al. (2021), Safta et al. (2021), and Zizi et al. (2021).

In the light of the foregoing, the business-oriented approach to financial risk management in entrepreneurship is visualized in Figure 1.

According to Figure 1, the business-oriented approach to financial risk management in entrepreneurship supposes that the interests of entrepreneurship and the interests of society (including company employees) contradict each other. Entrepreneurship and society oppose each other in the market economy. Companies use society to make profit: to exploit employees' labor and impose products that do not conform to consumer preferencesi.e., create unprofitable conditions of labor and purchase of products. Society is forced to perform transactions with entrepreneurship: employees agree to unfavorable labor conditions (without any alternative), and consumers agree to products that do not conform to their requirements to quality and/or price.

The SDGs are supported in society and reflect its interests. Entrepreneurship supports the SDGs through the manifestation of corporate social responsibility. The economic crisis is considered to be more important than the SDGs. A crisis increases the financial risks of entrepreneurship and paralyzes initiatives in the sphere of corporate social responsibility- 
support for the SDGs in entrepreneurship during a crisis is stopped (restored after the end of the crisis). The only beneficiary in this approach is entrepreneurship, while society suffers losses, which are increased manifold amid a crisis. Not only does a crisis limit the opportunities for implementing government programs in the sphere of sustainable development and the practice of corporate consumption, but it also leads to entrepreneurship's refusal to support the SDGs.

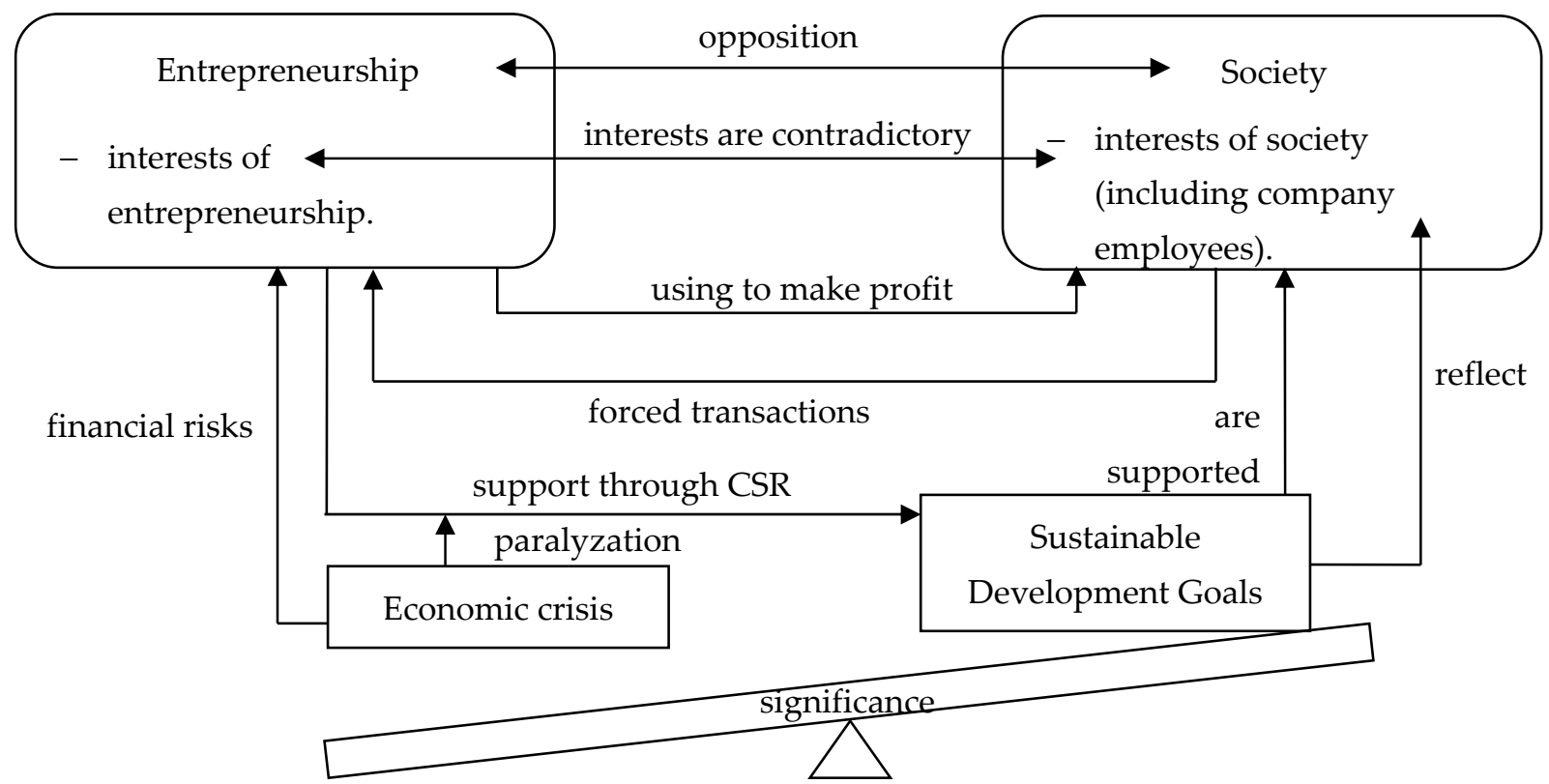

Figure 1. The business-oriented approach to financial risk management in entrepreneurship. Source: authors.

According to the described theories, corporate social responsibility is a source of the decrease of business risks. Since financial risks of business cannot be reduced through corporate social responsibility, its manifestation during the management of these risks is inexpedient, since it does not provide advantages in the short term (tactically). A crisis is treated as a phase of the economic cycle, characterized by high (and growing) financial risks; it is thus unfavorable for the manifestation of corporate social responsibility due to the impossibility of gaining advantage for the business.

Here the uncertainty (research gaps) regarding the following issues emerges:

- Whether long-term (strategic) advantages of the manifestation of corporate social responsibility during financial risk management could be obtained (first gap);

- If they could be obtained, how is it possible (using which approach) to obtain them, since the existing business-oriented approach to financial risk management of entrepreneurship fully excludes the manifestation of corporate social responsibility in the process of this management (second gap);

- If the appropriate approach is identified, whether it is possible to obtain long-term (strategic) advantages of the manifestation of corporate social responsibility during financial risk management in an economic crisis (third gap).

These research gaps are filled in this paper with the help of developing a sociallyoriented approach to financial risk management as the basis of support for the SDGs in entrepreneurship and substantiating its long-term (strategic) advantages and applicability amid a crisis. 


\section{Materials and Methods}

The goal of the paper predetermined the logical structure and methodology of the research. The level of financial risks and the impact of the COVID-19 pandemic and crisis on them are determined in the following way:

1. Systematization of entrepreneurship's financial risks and determination of the corresponding statistical indicators;

2. Calculation of the change of the indicators in 2019 compared to 2018 (before the pandemic and crisis), and in 2020 compared to 2019 (amid the pandemic and crisis) with the help of horizontal analysis;

3. Qualitative treatment of the level of risk amid the COVID-19 pandemic and crisis. First, from the position of the value of the risk, which could be as follows:

- Zero (risk is absent), if there is no negative dynamics of the indicator's change amid the pandemic;

- Low, if negative dynamics of the indicator's change amid the pandemic do not exceed $5 \%$ (in absolute value);

- Moderate, if negative dynamics of the indicator's change amid the pandemic are in the range of $5-10 \%$ (in absolute value);

- High, if negative dynamics of the indicator's change amid pandemic exceed 10\% (in absolute value).

Second, from the positions of the pandemic's impact on the change of risk, which could be as follows:

- Caused by the COVID-19 pandemic and crisis, if the dynamics of the indicator's change were positive before the pandemic, but became negative during the pandemic; - Increased by the COVID-19 pandemic and crisis, if the dynamics of the indicator's change before the pandemic had been negative and further grew during the pandemic.

This research was performed based on the materials of the World Bank (2021) and International Monetary Fund (2021) since these are reliable and respectable sources of international financial statistics. The research was performed based on the statistics for 2018-2020 broken down by three categories of countries:

- $\quad$ Underdeveloped countries (way behind developed and developing countries, with a slow rate of economic development);

- Developing countries (slightly behind developed countries, with a fast rate of economic development);

- Developed countries (OECD).

Five countries from each designated category were considered; the criteria of their inclusion in the sample were as follows: first, the highest (in their categories) value of GDP per capita growth in 2020 (annual percentage) in 2020, according to World Bank (2021). Second, availability of data for most of the indicators. The indicators that characterize the financial risks of entrepreneurship are as follows: Domestic credit to the private sector (\% of GDP) and lending interest rate (\%) (credit risks: Table 1); market capitalization of listed domestic companies (percentage of GDP) and inflation, consumer prices (annual percentage) (monetary risks: Table 2); total investment (percentage of GDP) and gross national savings (percentage of GDP) (market-determined risks: Table 3).

The data of the horizontal analysis were aggregated (their arithmetic means were calculated) for each category of countries. The advantage of performing the research based on the categories of countries is consideration of their specifics, as well as the possibility to assess the scale of financial risks of entrepreneurship (whether they are peculiar for the entire world economy or separate categories of countries, and which exactly). 
Table 1. Statistics characterizing credit risks in the highlighted categories of countries in 2018-2022.

\begin{tabular}{|c|c|c|c|c|c|c|c|c|}
\hline \multirow{2}{*}{$\begin{array}{l}\text { Category of } \\
\text { Countries }\end{array}$} & \multirow{2}{*}{ Country } & \multirow{2}{*}{$\begin{array}{l}\text { GDP per Capita } \\
\text { Growth in } 2020 \\
\text { (Annual \%) }\end{array}$} & \multicolumn{3}{|c|}{$\begin{array}{l}\text { Domestic Credit to the Private } \\
\text { Sector (\% of GDP) }\end{array}$} & \multicolumn{3}{|c|}{ Lending Interest Rate (\%) } \\
\hline & & & 2018 & 2019 & 2020 & 2018 & 2019 & 2020 \\
\hline \multirow{5}{*}{$\begin{array}{l}\text { Underdeveloped } \\
\text { countries }\end{array}$} & $\begin{array}{c}\text { Macao } \\
\text { SAR, China }\end{array}$ & -56.9 & 113.39 & 119.51 & 280.34 & 5.29 & 5.36 & 5.26 \\
\hline & Maldives & -33.2 & 31.65 & 32.01 & 49.02 & 10.68 & 11.52 & 11.60 \\
\hline & Fiji & -19.6 & 92.80 & 100.67 & 123.83 & 5.68 & 6.03 & 6,19 \\
\hline & Panama & -19.2 & 87.04 & 87.06 & 107.97 & 6.88 & 7.09 & 7.01 \\
\hline & Dominica & -16.9 & 47.49 & 43.01 & 57.14 & 7.81 & 7.54 & 6.94 \\
\hline \multirow{5}{*}{$\begin{array}{l}\text { Developing } \\
\text { countries }\end{array}$} & Philippines & -10.8 & 47.56 & 47.97 & 51.89 & 6.12 & 7.10 & no data \\
\hline & Kyrgyzstan & -10.5 & 23.37 & 24.61 & 28.46 & 19.51 & 19.00 & 17.04 \\
\hline & Mexico & -9.2 & 34.55 & 36.57 & 38.66 & 8.04 & 8.43 & 6.34 \\
\hline & India & -8.9 & 50.37 & 50.13 & 55.25 & 9.45 & 9.47 & 9.15 \\
\hline & Colombia & -7.8 & 49.57 & 51.50 & 54.08 & 12.11 & 11.77 & 9.85 \\
\hline \multirow{5}{*}{$\begin{array}{c}\text { Developed } \\
\text { countries (OECD) }\end{array}$} & Spain & -11.2 & 99.57 & 94.68 & 108.52 & no data & no data & no data \\
\hline & UK & -10.3 & 134.63 & 133.53 & 146.45 & no data & no data & no data \\
\hline & Italy & -8.6 & 76.71 & 74.28 & 83.58 & 2.68 & 2.60 & 2.33 \\
\hline & Greece & -8.2 & 91.66 & 80.93 & 82.09 & no data & no data & no data \\
\hline & France & -8.1 & 104.27 & 107.12 & 122.45 & no data & no data & no data \\
\hline
\end{tabular}

Source: Compiled by the authors based on World Bank data (2021).

Table 2. Statistics characterizing monetary risks in the highlighted categories of countries in 20182022.

\begin{tabular}{|c|c|c|c|c|c|c|c|}
\hline \multirow{2}{*}{$\begin{array}{l}\text { Category of } \\
\text { Countries }\end{array}$} & \multirow[t]{2}{*}{ Country } & \multicolumn{3}{|c|}{$\begin{array}{c}\text { Market Capitalization of Listed Domestic } \\
\text { Companies (\% of GDP) }\end{array}$} & \multicolumn{3}{|c|}{ Inflation, Consumer Prices (Annual \%) } \\
\hline & & 2018 & 2019 & 2020 & 2018 & 2019 & 2020 \\
\hline \multirow{5}{*}{$\begin{array}{l}\text { Underdeveloped } \\
\text { countries }\end{array}$} & $\begin{array}{l}\text { Macao SAR, } \\
\text { China }\end{array}$ & no data & no data & no data & 3.01 & no data & no data \\
\hline & Maldives & no data & no data & no data & -0.13 & 0.22 & -1.37 \\
\hline & Fiji & no data & no data & no data & 4.08 & 1.77 & -2.60 \\
\hline & Panama & 24.10 & 25.86 & 26.33 & 0.76 & -0.36 & -1.55 \\
\hline & Dominica & no data & no data & no data & 0.99 & 1.50 & no data \\
\hline \multirow{5}{*}{ Developing countries } & Philippines & 74.43 & 7.06 & 75.46 & 5.21 & 2.48 & 2.64 \\
\hline & Kyrgyzstan & no data & no data & no data & 1.54 & 1.13 & 6.33 \\
\hline & Mexico & 31.50 & 32.60 & 37.13 & 4.90 & 3.64 & 3.40 \\
\hline & India & 84.50 & 79.67 & 98.95 & 3.95 & 3.72 & 6.62 \\
\hline & Colombia & 31.07 & 40.83 & 39.18 & 3.24 & 3.53 & 2.52 \\
\hline \multirow{5}{*}{$\begin{array}{l}\text { Developed countries } \\
\text { (OECD) }\end{array}$} & Spain & 50.95 & 57.23 & 59.24 & 1.68 & 0.70 & -0.32 \\
\hline & UK & no data & no data & no data & 2.29 & 1.74 & 0.99 \\
\hline & Italy & no data & no data & no data & 1.14 & 0.61 & -0.14 \\
\hline & Greece & 18.09 & 26.13 & 26.92 & 0.63 & 0.25 & -1.25 \\
\hline & France & 84.81 & no data & no data & 1.85 & 1.11 & 0.48 \\
\hline
\end{tabular}


Table 3. Statistics characterizing market-determined risks in the highlighted categories of countries in 2018-2022.

\begin{tabular}{|c|c|c|c|c|c|c|c|}
\hline \multirow{2}{*}{$\begin{array}{l}\text { Category of } \\
\text { Countries }\end{array}$} & \multirow{2}{*}{ Country } & \multicolumn{3}{|c|}{ Total Investment (Percentage of GDP) } & \multicolumn{3}{|c|}{ Gross National Savings (Percentage of GDP) } \\
\hline & & 2018 & 2019 & 2020 & 2018 & 2019 & 2020 \\
\hline \multirow{5}{*}{$\begin{array}{l}\text { Underdeveloped } \\
\text { countries }\end{array}$} & $\begin{array}{c}\text { Macao SAR, } \\
\text { China }\end{array}$ & 17.213 & 14.120 & 27.605 & no data & no data & no data \\
\hline & Maldives & 20.000 & 20.000 & 20.000 & -8.386 & -6.451 & -9.925 \\
\hline & Fiji & 20.358 & 19.942 & 18.358 & no data & no data & no data \\
\hline & Panama & 41.453 & 39.292 & 28.547 & 33.803 & 34.302 & 30.876 \\
\hline & Dominica & 32.031 & 23.373 & 20.998 & -10.344 & -14.499 & -3.498 \\
\hline \multirow{5}{*}{$\begin{array}{l}\text { Developing } \\
\text { countries }\end{array}$} & Philippines & 27.151 & 26.402 & 17.383 & 24.591 & 25.593 & 20.973 \\
\hline & Kyrgyzstan & 27.734 & 26.370 & 18.648 & 15.682 & 14.270 & 23.155 \\
\hline & Mexico & 22.711 & 21.166 & 19.307 & 20.658 & 20.856 & 21.739 \\
\hline & India & 32.070 & 30.664 & 29.278 & 29.953 & 29.809 & 30.180 \\
\hline & Colombia & 21.195 & 21.509 & 19.011 & 17.105 & 17.023 & 15.576 \\
\hline \multirow{5}{*}{$\begin{array}{c}\text { Developed } \\
\text { countries (OECD) }\end{array}$} & Spain & 20.478 & 20.890 & 20.691 & 22.408 & 23.026 & 21.379 \\
\hline & UK & 17.765 & 18.340 & 17.221 & 14.084 & 15.246 & 13.508 \\
\hline & Italy & 18.529 & 18.011 & 17.500 & 21.040 & 21.216 & 21.048 \\
\hline & Greece & 13.337 & 12.689 & 13.450 & 9.766 & 10.456 & 6.029 \\
\hline & France & 23.857 & 24.365 & 23.676 & 23.026 & 24.074 & 21.777 \\
\hline
\end{tabular}

Source: Compiled by the authors based on World Bank data (2021).

Mathematical tools were used to check the given hypotheses. The data for 2018-2020 were unified in a common data array (45 observations) for each indicator. The method of regression analysis was used to find the dependence of the indicators of financial risks (from Tables 1-3) on the Sustainable Development Index. The statistics on this index in the distinguished categories of countries in 2018-2020 are given in Table 4.

Table 4. Statistics on sustainable development in the distinguished categories of countries in 20182020.

\begin{tabular}{ccccc}
\hline \multirow{2}{*}{$\begin{array}{c}\text { Category of } \\
\text { Countries }\end{array}$} & Country & \multicolumn{3}{c}{ Sustainable Development Index, Score 0-100 } \\
\cline { 2 - 5 } & & $\mathbf{2 0 1 8}$ & $\mathbf{2 0 1 9}$ & $\mathbf{2 0 2 0}$ \\
\hline \multirow{3}{*}{$\begin{array}{c}\text { Mnderdeveloped } \\
\text { countries }\end{array}$} & Maldives & 70.1 & 73.2 & 73.89 \\
& Fiji & 0 & 72.1 & 67.59 \\
& Panama & 64.9 & 70.1 & 69.95 \\
& Dominica & 0 & 66.3 & 69.19 \\
& Philippines & 65 & 64.9 & 0 \\
\hline \multirow{2}{*}{ Developing countries } & Kyrgyzstan & 70.3 & 71.6 & 73.01 \\
& Mexico & 65.2 & 68.5 & 70.44 \\
& India & 59.1 & 61.1 & 61.92 \\
& Colombia & 66.6 & 69.6 & 70.91 \\
\hline \multirow{2}{*}{ Developed countries } & Spain & 75.4 & 77.8 & 78.11 \\
(OECD) & UK & 78.7 & 79.4 & 79.79 \\
& Italy & 74.2 & 75.8 & 77.01 \\
& Greece & 70.6 & 71.4 & 74.33 \\
& France & 81.2 & 81.5 & 81.13 \\
\hline
\end{tabular}


For the econometric modeling, the indicators were assigned symbols. Financial risksRisk $_{\text {fin }}$; the Sustainable Development Index, as a factor that has a potential influence on them $-S D G_{\text {ind }}$. The research model of this paper has the following form:

$$
\text { Risk }_{\text {fin }}=\alpha+\beta \times \text { SDG }_{\text {ind }}
$$

In Equation (1) $\alpha$ is the constant, and $\beta$ is the coefficient of regression, which shows the character of the connection between variables. The reliability of the results of the regression analysis was checked with the help of multiple R (correlation coefficient), significance F, and t-Stat.

The hypothesis was proved if, for most of the indicators of financial risks, their positive dependence (corresponding values of the coefficients of regression) on the Sustainable Development Index was discovered, but the connection between the indicators was weak and/or insufficiently reliable. This is proof of the potential of sustainable development to reduce financial risks, but the impossibility of developing this potential using the current business-oriented approach to managing the financial risks in entrepreneurship. This is an argument in favor of the transition to a new socially-oriented approach to managing the financial risks in entrepreneurship.

For the demonstration of the socially-oriented approach to financial risk management in entrepreneurship, we used the graphical method (visualization). To identify its specific features and advantage, we used the method of comparative analysis to compare the proprietary approach to the business-oriented approach. To assess the applicability of the socially-oriented approach to financial risk management in entrepreneurship during a crisis we used the method of SWOT analysis, since it allows for the systemic determination and consideration of the strengths, weaknesses, opportunities, and threats of the new approach and compiling the most comprehensive and correct opinion of it.

\section{Results}

To determine the level of financial risks and the impact of the COVID-19 pandemic and crisis on them, we conducted a horizontal analysis of the data from Tables 1-3; its results were systematized and critically reconsidered (scientific treatment is provided), as shown in Table 5.

As shown in Table 5, the first distinguished financial risk of entrepreneurship is connected to the deficit of financial resources and forced increase in loan assets. The indicator of this risk is domestic credit to private sector (percentage of GDP). The negative dynamics of this indicator envisage its increase; it has been determined in:

- $\quad$ Underdeveloped countries, where domestic credit to the private sector grew in 2019 (in comparison with 2018 ) by $1.12 \%$ (the risk was present before the pandemic, but it was low), and in 2020 (in comparison with 2019) by 53.52\% (the risk grew manifold during the pandemic);

- In developing countries, where domestic credit to the private sector grew in 2019 (in comparison with 2018) by 3.09\% (the risk was present before the pandemic, but it was low), and in 2020 (in comparison with 2019) by 8.95\% (the risk grew to the moderate level during the pandemic);

- In developed countries, where domestic credit to the private sector in 2019 (in comparison with 2018) demonstrated positive dynamics (9.357\%, i.e., there was no risk before the pandemic), and in 2020 (in comparison with 2019) grew by 10.51\% (high risk emerged during the pandemic).

Given this, there is a high risk of deficit of financial resources and a forced increase in loan assets, which were caused by the COVID-19 pandemic and crisis and are most evident in underdeveloped countries. 
Table 5. Analysis of the level of financial risks and the impact of the COVID-19 pandemic and crisis on them.

\begin{tabular}{|c|c|c|c|c|}
\hline Financial Risk & $\begin{array}{l}\text { Indicator of } \\
\text { Financial Risk }\end{array}$ & $\begin{array}{l}\text { Change of Indicator: } \\
\text { 2019-2018, \% }\end{array}$ & $\begin{array}{l}\text { Change of Indicator: } \\
2020-2019, \%\end{array}$ & $\begin{array}{l}\text { Level of Risk during the } \\
\text { COVID-19 Pandemic and Crisis }\end{array}$ \\
\hline \multirow{6}{*}{$\begin{array}{c}\text { Deficit of financial resources } \\
\text { and forced increase in } \\
\text { loan assets }\end{array}$} & \multirow{6}{*}{$\begin{array}{l}\text { Domestic credit to } \\
\text { private sector } \\
(\% \text { of GDP) }\end{array}$} & \multicolumn{2}{|c|}{ Underdeveloped countries } & \multirow{6}{*}{$\begin{array}{l}\text { High risk, caused by the } \\
\text { COVID-19 pandemic and crisis }\end{array}$} \\
\hline & & 1.12 & 53.52 & \\
\hline & & \multicolumn{2}{|c|}{ Developing countries } & \\
\hline & & 3.09 & 8.95 & \\
\hline & & \multicolumn{2}{|c|}{ Developed countries } & \\
\hline & & -3.57 & 10.51 & \\
\hline $\begin{array}{l}\text { Growth of lending } \\
\text { interest rate }\end{array}$ & Lending interest rate (\%) & Positiv & nanges & Risk is absent \\
\hline \multirow{4}{*}{$\begin{array}{l}\text { Decrease of market } \\
\text { capitalization of business }\end{array}$} & \multirow{4}{*}{$\begin{array}{l}\text { Market capitalization of } \\
\text { listed domestic } \\
\text { companies (\% of GDP) }\end{array}$} & \multicolumn{2}{|c|}{ Underdeveloped countries } & \multirow{4}{*}{$\begin{array}{l}\text { Moderate risk, further increased by } \\
\text { the COVID-19 pandemic and crisis }\end{array}$} \\
\hline & & 7.30 & 1.82 & \\
\hline & & Develope & ountries & \\
\hline & & 28.39 & 3.27 & \\
\hline \multirow{2}{*}{$\begin{array}{l}\text { Growth of purchasing prices } \\
\text { (prime cost) }\end{array}$} & \multirow{2}{*}{$\begin{array}{l}\text { Inflation, consumer } \\
\text { prices (annual \%) }\end{array}$} & \multicolumn{2}{|c|}{ Developing countries } & High risk, caused by the \\
\hline & & -20.32 & 101.88 & COVID-19 pandemic and crisis \\
\hline \multirow{4}{*}{ Deficit of investments } & \multirow{4}{*}{$\begin{array}{l}\text { Total investment } \\
\quad(\% \text { of GDP) }\end{array}$} & \multicolumn{2}{|c|}{ Developing countries } & \multirow{4}{*}{$\begin{array}{l}\text { High risk, further increased by the } \\
\text { COVID-19 pandemic and crisis }\end{array}$} \\
\hline & & -3.48 & -17.67 & \\
\hline & & Develope & ountries & \\
\hline & & -0.06 & -1.34 & \\
\hline \multirow{2}{*}{$\begin{array}{l}\text { Reduction of the volume of } \\
\text { effective demand }\end{array}$} & \multirow{2}{*}{$\begin{array}{l}\text { Gross national savings } \\
(\% \text { of GDP })\end{array}$} & \multicolumn{2}{|c|}{ Developing countries } & High risk, caused by the \\
\hline & & -0.99 & 8.24 & COVID-19 pandemic and crisis \\
\hline
\end{tabular}

Source: authors.

The second financial risk of entrepreneurship envisages the increase in credit interest rates. The indicator of this risk is lending interest rate (\%). The negative dynamics of this indicator envisage its increase, but it has not been determined in any category of countries. Thus, the risk is absent.

The third financial risk of entrepreneurship is connected to a decrease in the market capitalization of the business. The indicator of this risk is market capitalization of listed domestic companies (percentage of GDP). The negative dynamics of this indicator envisage the reduction in growth of market capitalization of business in 2020-2019 compared to 2019-2018; the negative dynamics have been determined in:

- Underdeveloped countries, where market capitalization of listed domestic companies grew in 2019 (in comparison with 2018) by 7.30\%, and in 2020 (in comparison with 2019 ) only by $1.82 \%$ (the pandemic significantly reduced the growth);

- Developed countries, where market capitalization of listed domestic companies grew in 2019 (in comparison with 2018) by 28.39\%, and in 2020 (in comparison with 2019) only by $3.27 \%$ (the pandemic significantly reduced the growth).

Given this, the moderate risk of reduction of market capitalization of business is observed, which was further increased by the COVID-19 pandemic and which is most evident in underdeveloped and developed countries.

The fourth financial risk of entrepreneurship is the growth of purchasing prices (prime cost). The indicator of this risk is inflation, consumer prices (annual percentage). The negative dynamics of this indicator envisages its increase; the negative dynamics have been determined only in developing countries, where inflation, or consumer prices, in 2019 (in comparison with 2018$)$ demonstrated positive dynamics $(-20.32 \%$, i.e., the risk was absent before the pandemic: there was deflation), and in 2020 (in comparison with 2019) it grew by $101.88 \%$ (high risk emerged during the pandemic). Therefore, a high risk of growth of 
purchasing prices (prime cost) is observed; it was caused by the COVID-19 pandemic and crisis and it is most evident in developing countries.

The fifth financial risk of entrepreneurship is the deficit of investments. The indicator of this risk is total investment (percentage of GDP). The negative dynamics of this indicator envisage its decrease; the negative dynamics have been determined in:

- Developing countries, where total investment reduced in 2019 (in comparison with 2018) by 3.48\% (the risk existed before the pandemic, but it was low) and in 2020 (in comparison with 2019 by $17.67 \%$ (during the pandemic, the risk grew to a high level;) - Developed countries, where total investment reduced in 2019 (in comparison with 2018) by $0.06 \%$ (the risk existed before the pandemic, but it was low) and in 2020 (in comparison with 2019) by $1.34 \%$ (during the pandemic, the risk grew but remained at a low level).

Therefore, a high risk of the deficit of investments is observed, which was further increased by the COVID-19 pandemic and crisis and which is most evident in developing countries.

The sixth financial risk of entrepreneurship is the reduction of the volume of effective demand. The indicator of this risk is gross national savings (percentage of GDP). The negative dynamics of this indicator envisage its increase; the negative dynamics have been determined in developing countries, where gross national savings reduced in 2019 (in comparison with 2018) by $0.99 \%$ (the risk was absent before the pandemic), and in 2020 (in comparison with 2019) grew by $8.24 \%$ (a moderate risk emerged under the conditions of the pandemic). Therefore, there is a high risk of the reduction of the volume of effective demand, caused by the COVID-19 pandemic and crisis, which is most evident in developing countries.

The results of the horizontal analysis demonstrate high financial risks, which grew in 2020. To identify ways of reducing the discovered financial risks, the method of regression analysis was used (based on the data from Tables 1-4) to find their dependence on the Sustainable Development Index. The results are given in Table 6.

Table 6. Results of the regression analysis.

\begin{tabular}{|c|c|c|c|c|c|c|}
\hline \multirow[b]{2}{*}{$\begin{array}{l}\text { Regression } \\
\text { Statistics }\end{array}$} & \multicolumn{6}{|c|}{ Regression Models (Risk fin ) } \\
\hline & $\begin{array}{l}\text { Domestic } \\
\text { Credit to } \\
\text { Private Sector } \\
\text { (\% of GDP) }\end{array}$ & $\begin{array}{c}\text { Lending } \\
\text { Interest Rate } \\
(\%)\end{array}$ & $\begin{array}{c}\text { Market } \\
\text { Capitalization of } \\
\text { Listed Domestic } \\
\text { Companies ( } \% \text { of } \\
\text { GDP) }\end{array}$ & $\begin{array}{c}\text { Inflation, } \\
\text { Consumer } \\
\text { Prices (Annual } \\
\% \text { ) }\end{array}$ & $\begin{array}{c}\text { Total } \\
\text { Investment } \\
\text { (\% of GDP) }\end{array}$ & $\begin{array}{c}\text { Gross National } \\
\text { Savings (\% of } \\
\text { GDP) }\end{array}$ \\
\hline $\begin{array}{c}\text { Multiple R } \\
\text { (correlation) }\end{array}$ & 0.2970 & 0.2333 & 0.1752 & 0.0338 & 0.1614 & 0.5392 \\
\hline Significance F & 0.05 & 0.12 & 0.25 & 0.83 & 0.29 & 0.0001 \\
\hline $\mathrm{t}$-Stat & 2.04 & -1.57 & 1.17 & -0.22 & -1.07 & 4.20 \\
\hline Constant $(\alpha)$ & 42.13 & 9.36 & 8.79 & 1.81 & 25.06 & -4.88 \\
\hline $\begin{array}{l}\text { Coefficient of } \\
\text { regression }(\beta)\end{array}$ & 0.58 & -0.05 & 0.22 & -0.003 & -0.04 & 0.30 \\
\hline $\begin{array}{l}\text { Character of the } \\
\text { impact of } \mathrm{SDG}_{\mathrm{S}} \\
\text { on financial risk }\end{array}$ & contradictory & positive & positive & positive & negative & positive \\
\hline
\end{tabular}

Source: calculated and compiled by the authors.

The results from Table 6 show that an increase in the Sustainable Development Index by 1 point leads to the following:

- Increase in domestic credit to private sector by $0.58 \%$ of GDP. On the one hand, the support of the SDG increases business solvency, i.e., increases the accessibility of bor- 
rowed resources to the business. On the other hand, the financial leverage of business decreases (the share of borrowed assets in the structure of private entrepreneurial capital grows). Therefore, the influence of the Sustainable Development Index on this financial risk is contradictory. The regression model is sufficiently reliable-this is shown by the moderate value of the correlation coefficient $(29.70 \%)$ and the significance $F$ value of 0.12 ;

- $\quad$ Decrease in lending interest rate by $0.05 \%$. This could be explained by government support for the corporate social (and ecological) responsibility of business through the expansion of access and creation of favorable conditions for subsidized credit. The influence of the Sustainable Development Index on this financial risk is positive and moderate (correlation: $23.33 \%$ ), but the regression model is insufficiently reliable-this is demonstrated by the significance $F$ value of 0.25 ;

- Increase in market capitalization of listed domestic companies by $0.22 \%$ of GDP. This is proof of the clear contribution that support of the SDGs has to the increase in market capitalization of the business. The influence of the Sustainable Development Index on this financial risk is positive and moderate (correlation: 17.52\%), but the regression model is insufficiently reliable, which is shown by the significance F value of 0.25 ;

- Decrease in inflation, consumer prices (annual) by $0.003 \%$. Therefore, the systemic support of the SDGs at all stages of the added value chain reduced the risk of the growth of purchasing prices (costs). The influence of the Sustainable Development Index on this financial risk is positive and moderate (correlation: $3.38 \%$ ), but the regression model is insufficiently reliable, which is shown by the significance $F$ value of 0.83 ;

- Decrease in total investment by $0.04 \%$ of GDP. This contradictory result should be treated with caution during the differentiation of regular (commercial) and responsible investments. There is no doubt that the support of the SDGs in business ensures an inflow of responsible investments, but regular (commercial) investments might reduce in this case. For this risk, moderate correlation (16.14\%) combined with insufficient reliability of the regression model (significance $F=0.29$ ) show the inexpedience of further consideration of this risk due to its contradictory character;

- Increase in gross national savings by $0.30 \%$ of GDP. Therefore, the influence of the Sustainable Development Index on this financial risk is positive. The regression model is sufficiently reliable-this is shown by the high value of the correlation coefficient (53.92\%) and significance F value of 0.0001 .

According to the research model (1), the obtained results of the regression analysis demonstrated a positive dependence of most of the indicators of financial risks on the Sustainable Development Index, but the connection between the indicators is weak and insufficiently reliable in most cases. This is a sign of the unrealized potential of sustainable development in reducing financial risks-a drawback of the current, business-oriented approach, to managing the financial risks in entrepreneurship.

This is an argument in favor of the transition to the new socially-oriented approach to managing the financial risks in entrepreneurship. To strengthen the given argument, it should be added that in the only reliable model of regression, the maximization $(+48.11 \%)$ of the Sustainable Development Index leads to an increase in gross national savings of $77.93 \%$ : from $14.19 \%$ of GDP in 2020 to $25.24 \%$ of GDP.

The increased level of most of the financial risks (due to the COVID-19 pandemic and crisis in 2020), as well as the unrealized potential of the reduction of these risks through the support of the SDGs in business, shows that the business-oriented approach shows low effectiveness and does not allow coping with financial risks in entrepreneurship - this is true for all categories of countries (including developed countries). As a prospective alternative, we propose a new socially-oriented approach. The comparative characteristics of these approaches are given in Table 7. 
Table 7. Comparative characteristics of the alternative approaches to financial risk management in entrepreneurship.

\begin{tabular}{|c|c|c|c|}
\hline \multicolumn{2}{|c|}{ Characteristics of the Approach } & Business-Oriented Approach & Socially-Oriented Approach \\
\hline \multicolumn{2}{|c|}{ Primary (key) interests } & $\begin{array}{l}\text { Interests of business are sought to } \\
\text { the detriment of society's interests }\end{array}$ & $\begin{array}{l}\text { Society's interests ensure the } \\
\text { achievement of interests of business }\end{array}$ \\
\hline \multicolumn{2}{|c|}{ Role of financial risks in the system of business risks } & Central & Peripheral \\
\hline \multicolumn{2}{|c|}{ Priority of financial risk management } & $\begin{array}{l}\text { Instantaneous and } \\
\text { maximum reduction }\end{array}$ & $\begin{array}{c}\text { Preservation of corporate } \\
\text { knowledge and positive image }\end{array}$ \\
\hline \multirow{6}{*}{$\begin{array}{l}\text { Measures of } \\
\text { financial risk } \\
\text { management }\end{array}$} & $\begin{array}{l}\text { Deficit of financial resources and } \\
\text { forced increase in loan assets }\end{array}$ & \multirow{4}{*}{$\begin{array}{l}\text { 'Shadowization' of the activities to } \\
\text { reduce the tax burden; } \\
\text { refusal of responsible innovations }\end{array}$} & \multirow{4}{*}{$\begin{array}{c}\text { Optimization of business processes } \\
\text { to reduce expenditures; } \\
\text { preservation of } \\
\text { responsible innovations }\end{array}$} \\
\hline & Increase in credit interest rates & & \\
\hline & $\begin{array}{c}\text { Reduction of market } \\
\text { capitalization of business }\end{array}$ & & \\
\hline & Deficit of investments & & \\
\hline & $\begin{array}{l}\text { Growth of purchasing prices } \\
\text { (prime cost) }\end{array}$ & $\begin{array}{l}\text { Increase in prices (transferring } \\
\text { increased expenditures on buyers) }\end{array}$ & $\begin{array}{l}\text { Flexible pricing policy given the } \\
\text { specifics of the categories } \\
\text { of consumers }\end{array}$ \\
\hline & $\begin{array}{l}\text { Reduction of the volume of } \\
\text { effective demand }\end{array}$ & $\begin{array}{l}\text { Reduction of product quality with } \\
\text { unchanged or increased prices }\end{array}$ & $\begin{array}{c}\text { Preservation or equal reduction of } \\
\text { quality and prices }\end{array}$ \\
\hline
\end{tabular}

Source: authors.

According to Table 7, the primary (key) interests in the business-oriented approach are the interests of business, which are achieved to the detriment of society's interests. In the socially-oriented approach, these are society's interests, which ensure the achievement of the interests of business. Financial risks have a central place in the system of business risks in the business-oriented approach, and a peripheral place in the socially-oriented approach. The priority of financial risk management in the business-oriented approach is instantaneous and maximum reduction, and in the socially-oriented approach, the preservation of corporate knowledge and positive image.

The business-oriented approach is based on the following measures of financial risk management:

- 'Shadowization' of activities to reduce the tax burden, refusal of responsible innovations to manage the risks of the deficit of financial resources, forced increase in loan assets, an increase in credit interest rates, reduction of market capitalization of the business, and deficit of investments;

- Increase in prices (transferring the increased expenditure to consumers) to manage the risk of purchasing power prices' (prime cost) growth;

- $\quad$ Reduction of product quality with unchanged or increased prices during the management of the risk of reduction of the effective demand volume.

The socially-oriented approach offers the following alternative measures of financial risk management:

- Optimization of business processes to reduce expenditures and preservation of responsible innovations to manage the risks of the deficit of financial resources, as well as the forced increase in loan assets, an increase in credit interest rates, reduction of market capitalization of the business, and the deficit of investments;

- $\quad$ Flexible pricing policy given the specifics of consumer categories to manage the risk of growth of purchasing prices (prime cost);

- Preservation or equal reduction of quality and prices to manage the risk of reduction of the volume of effective demand.

The advantages (compared to the business-oriented approach) of the socially-oriented approach to financial risk management in entrepreneurship are as follows: 
- $\quad$ Stability and consistency of corporate culture and its harmonious combination with the practice of crisis management of the responsible business;

- Invariably high competitive advantages in loyalty: business possesses a substantial social capital; loyalty of employees (best personnel, increased efficiency, and unique corporate knowledge) and loyalty of consumers (stable and high demand, reduced price-demand elasticity).

To determine the applicability of the socially-oriented approach to financial risk management in entrepreneurship in a crisis, we performed a SWOT analysis (Table 8).

Table 8. SWOT analysis of the socially-oriented approach to financial risk management in entrepreneurship in conditions of crisis.

\begin{tabular}{|c|c|}
\hline Strengths (S) & Weaknesses (W) \\
\hline $\begin{array}{l}\text { - Preservation/increase in the social capital of business; } \\
\text { - Large potential and accelerated restoration of business } \\
\text { after a crisis; }\end{array}$ & $\begin{array}{l}\text { - The most evident financial losses due to a crisis; } \\
\text { - } \quad \text { Large financial risks and the need for reserves to take } \\
\text { the risks. }\end{array}$ \\
\hline Opportunities (O) & Threats (T) \\
\hline $\begin{array}{l}\text { - Containment of financial risks of business by the } \\
\text { government; } \\
\text { - Compensation for losses of responsible business by } \\
\text { government and market institutions; } \\
\text { - } \begin{array}{l}\text { Development of the system of insurance of financial risks } \\
\text { of business; }\end{array} \\
\text { - Increase in the accessibility of the measures of the } \\
\text { socially-oriented approach to financial risk management. }\end{array}$ & $\begin{array}{l}\text { - } \quad \text { Lasting (ongoing) crises; } \\
\text { - Underdevelopment of the culture of responsible } \\
\text { production and consumption, low support for the SDGs } \\
\text { from society; } \\
\text { - High competition/monopolization of the market by } \\
\text { companies with low corporate social responsibility. }\end{array}$ \\
\hline
\end{tabular}

Source: authors.

According to Table 8, the strengths of the socially-oriented approach to financial risk management in entrepreneurship in a crisis are preservation/increase in the social capital of business and the large potential and accelerated restoration of business after a crisis.

The weaknesses of the new approach are the high financial losses due to the crisis and high financial risks and the need for reserves to take these risks. This makes the offered approach the most accessible and attractive for large-scale entrepreneurship.

The opportunities of using the socially-oriented approach to financial risk management in entrepreneurship in a crisis include containment of the financial risks of business by the government, compensation for losses of responsible business by government and market institutions, development of the system of insurance of financial risks of business, and an increase in accessibility of the measures of the socially-oriented approach to financial risk management.

The threats of the use of the socially-oriented approach to financial risk management in entrepreneurship in a crisis include lasting (ongoing) crises, underdevelopment of the culture of responsible production and consumption, low support for the SDGs from society, and high competition/monopolization of the market by companies with low corporate social responsibility.

\section{Discussion}

The results obtained add to the existing scientific views (Bae et al. 2021; Havlinova and Kukacka 2021; Zhang et al. 2022) of the contribution of corporate social responsibility to the financial risk management of business. They are expressed in the following:

- Quantitative measuring of this contribution. It has been established that an increase in the Sustainable Development Index by 1 point leads to an increase in market capitalization of listed domestic companies by $0.22 \%$ of GDP. The correlation between the indicators is moderate: the change of the market capitalization of business by $17.52 \%$ is due to the change in the Sustainable Development Index; 
- Specification of the condition for achieving this contribution. This condition is as follows: corporate social responsibility must completely thread the activity of business structures and be the core of their functioning, based on the socially-oriented approach to financial risk management. The use of the business-oriented approach with the secondary characteristics (small significance or small scale) of corporate social responsibility does not allow developing the potential contribution of corporate social responsibility to financial risk management. General sustainable development at the level of economy with insufficient support of the SDGs from business cannot ensure the reliable connection between the market capitalization of business and sustainable development. A solution here is corporate social responsibility with the focus on the support of SDGs in business, implemented with the help of the socially-oriented approach to financial risk management.

In contrast to other research (Liang et al. 2022; Lopata and Rogatka 2021; Magrizos et al. 2021), it has been proved that before (2018-2019) and during (2020) the crisis, corporate social responsibility made a significant contribution to financial risk management in business. This responsibility is critically important during a crisis, to reduce the financial risks of business and support its stability.

This paper's contribution to the literature consists in the development of a sociallyoriented approach to financial risk management in entrepreneurship (visualized in Figure 2).

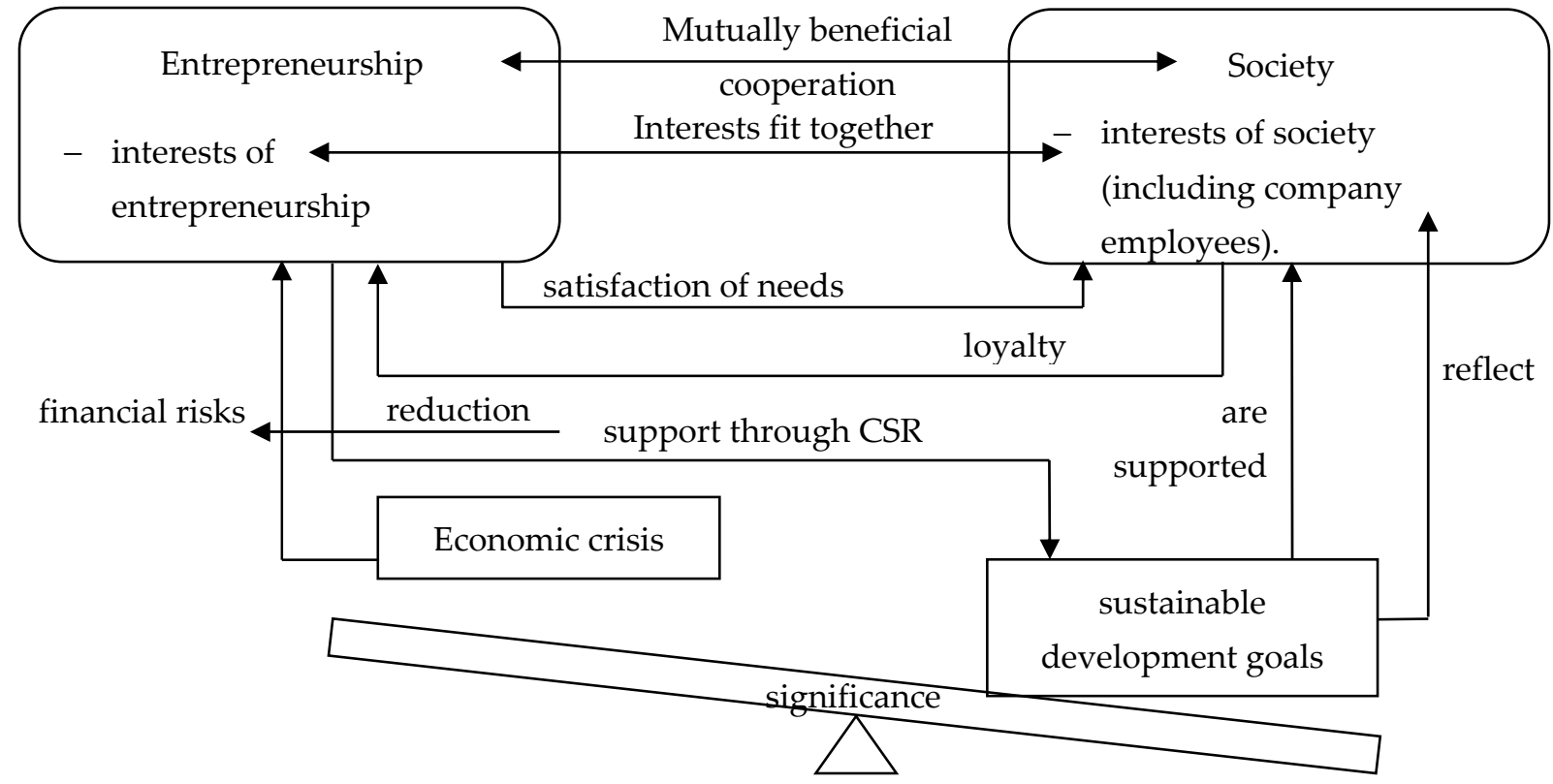

Figure 2. Socially-oriented approach to financial risk management in entrepreneurship. Source: authors.

As Figure 2 suggests, the socially-oriented approach to financial risk management in entrepreneurship implies that the interests of entrepreneurship and society (including company employees) fit together. Entrepreneurship and society in the market economy have mutually beneficial cooperation. Companies satisfy society's needs-providing consumers with the possibility to purchase products that correspond to their preferences and providing employees with the possibility to realize their labor potential. Society manifests loyalty toward entrepreneurship and voluntarily performs transactions with it: employees receive favorable conditions of labor, and consumers receive products that meet their expectations as to the quality and/or price.

The SDGs are supported in society and reflect its interests. Entrepreneurship supports the SDGs through the manifestation of corporate social responsibility. The economic crisis is less important than the SDGs-i.e., it fades into the background. The crisis increases financial risks, but entrepreneurship successfully reduces/overcomes these financial risks 
with the help of corporate social responsibility. In the new approach, the beneficiaries are entrepreneurship (reduction of financial risks, increased robustness against crisis) and society (business covers society's losses that are caused by the crisis). The crisis still limits opportunities for implementing government programs in the sphere of sustainable development and the practice of corporate consumption, but support for the SDGs in entrepreneurship allows compensating for losses, preserving the achieved results, and the rate of sustainable development.

Unlike the existing studies of financial risk management in entrepreneurship, in particular, the works Jiang and Feng (2021), Kruger et al. (2021), Safta et al. (2021), and Zizi et al. (2021), the socially-oriented approach to financial risk management in entrepreneurship does the following:

- $\quad$ Provides long-term (strategic) advantages of the manifestation of corporate social responsibility during financial risk management: (1) stability and consistency of corporate culture, its harmonious combination with the practice of crisis management of responsible business; (2) invariable high competitive advantages in loyalty (thus filling the first gap);

- Implies the manifestation of corporate social responsibility in the process of financial risk management of entrepreneurship, i.e., provides continuous support for the SDGs in the business environment (thus filling the second gap);

- $\quad$ The described long-term (strategic) advantages of the manifestation of corporate social responsibility during the management of financial risks could be obtained during an economic crisis (thus filling the third gap).

Thus, the developed socially-oriented approach to financial risk management is the alternative to the business-oriented approach; it forms the basis for support for SDGs in entrepreneurship (continuously, including in a crisis), fills all research gaps, allows for the achievement of long-term (strategic) advantages, and raises the effectiveness of financial risk management of entrepreneurship during a crisis.

\section{Conclusions}

This paper has provided a scientifically substantiated answer to the proposed research question and demonstrated that the SDGs could be supported by business during financial risk management. Toward this aim, a socially-oriented approach to financial risk management in entrepreneurship has been developed and is offered for use during economic crises.

As a result of the performed research, it has been established that the level of financial risks and the impact of the COVID-19 pandemic and crisis on them are high; we have determined the following:

- High risk of a deficit of financial resources and forced increase in loan assets caused by the COVID-19 pandemic and crisis - this is most evident in underdeveloped countries.

- Moderate risk of reduction of market capitalization of business, further increased by the COVID-19 pandemic and crisis-this is most evident in underdeveloped and developed countries.

- High risk of growth of purchasing prices (prime cost), caused by the COVID-19 pandemic and crisis-this is most evident in developing countries.

- $\quad$ The high risk of a deficit of investments, further increased by the COVID-19 pandemic and crisis-this is most evident in developing countries.

- High risk of reduction of the volume of effective demand, caused by the COVID-19 pandemic and crisis-this is most evident in developing countries.

The increased level of most financial risks due to the COVID-19 pandemic and crisis in 2020 shows that the business-oriented approach is characterized by low effectiveness and does not allow coping with financial risks in entrepreneurship; this is true for all categories of countries (including developed countries). A prospective alternative is the new socially-oriented approach, the specific features of which are as follows: 
- $\quad$ Establishing society's interests as primary (key) interests, which ensure the achievement of the interests of both the economy and society;

- $\quad$ Peripheral place of financial risks in the system of business risks;

- The priority of financial risk management is the preservation of corporate knowledge and a positive image;

- $\quad$ Prospective measures of financial risk management are recommended; they include optimization of business processes to reduce expenditures, preservation of responsible innovations, flexible pricing policy given the specifics of the categories of consumers, and preservation or equal reduction of quality and prices.

Its advantages (as compared to the business-oriented approach) from the position of financial risk management are, first, stability and consistency of corporate culture and its harmonious combination with the practice of crisis management of the responsible business, and second, invariable high competitive advantages in loyalty; these advantages predetermine the expedience of its use in an economic crisis.

The theoretical value of this paper consists in the offering and scientific substantiation of a new hypothesis: that the SDGs could and should be continuously supported by business during financial risk management with the help of the socially-oriented approach, which is accessible and expedient for use in an economic crisis.

The practical value of the obtained results consists in the following: the developed new (alternative) socially-oriented approach to financial risk management in entrepreneurship allows increasing the effectiveness of financial risk management in entrepreneurship and raising its robustness against the current COVID-19 crisis.

The social importance of the conclusions and obtained results is that the developed new (alternative) socially-oriented approach to financial risk management in entrepreneurship allows for and stimulates continuous support for the SDGs in entrepreneurship during the entire economic cycle, including the phase of the crisis. This allows for the maximization of achievements in the sphere of sustainable development and the increase in its rate.

The obtained results are limited by the hypothesis since its testing was complicated due to the deficit of isolated, full-scale, and compatible (for different years) statistics on support for the SDGs in entrepreneurship during a long period that would cover various phases of an economic cycle. During the period of the 2000 financial crisis, the SDGs were not yet adopted, and there were no statistics on them, and under the conditions of the current recession caused by the COVID-19 pandemic and lockdown in 2020-2021, there is a deficit of factual data and a lack of experience (the crisis continues) to compare data from a different phase of the economic cycle (comparison will be possible only when the crisis ends).

Future studies should be devoted to the compilation of an empirical base (official statistics and alternative data) on support for the SDGs in entrepreneurship, the approbation of the developed socially-oriented approach to financial risk management in entrepreneurship, and verification of the proposed hypothesis.

Author Contributions: Writing—original draft, A.N.Z., M.V.K., A.V.B., S.M.S., T.M.R. and S.V.P.; Writing-review \& editing, A.N.Z., M.V.K., A.V.B., S.M.S., T.M.R. and S.V.P. All authors have read and agreed to the published version of the manuscript.

Funding: This research received no external funding.

Institutional Review Board Statement: Not applicable.

Informed Consent Statement: Not applicable.

Conflicts of Interest: The authors declare no conflict of interest. 


\section{References}

Aloui, Mouna, Bassem Salhi, and Anis Jarboui. 2019. Market risk, corporate governance, and the regulation during the recent financial crisis: The French context. International Journal of Managerial Finance 15: 700-18. [CrossRef]

Arslan-Ayaydin, Özgür, and James Thewissen. 2016. The financial reward for environmental performance in the energy sector. Energy E Environment 27: 389-413.

Ayadi, Mohamed, Walid Ben Omrane, Jiayu Wang, and Robert Welch. 2022. Senior official speech attributes and foreign exchange risk around business cycles. International Review of Financial Analysis 80: 102011. [CrossRef]

Bae, Kee-Hong, Sadok El Ghoul, Zhaoran Jason Gong, and Omrane Guedhami. 2021. Does CSR matter in times of crisis? Evidence from the COVID-19 pandemic. Journal of Corporate Finance 67: 101876. [CrossRef]

Barontini, Roberto, and Jonathan Taglialatela. 2021. Patents and small business risk: Longitudinal evidence from the global financial crisis. Journal of Small Business and Enterprise Development. [CrossRef]

Berkman, Henk, Michelle Li, and Helen Lu. 2021. Trust and the value of CSR during the global financial crisis. Accounting and Finance 61: 4955-65. [CrossRef]

Bratis, Tteodoros, Nikiforos Laopodis, and Georgios Kouretas. 2020. Systemic risk and financial stability dynamics during the Eurozone debt crisis. Journal of Financial Stability 47: 100723. [CrossRef]

Çağıl, Gulcan, and Sibel Yilmaz Turkmen. 2017. Renewable energy financing with a sustainable financial system following the 2008 financial crisis in developing countries. Contributions to Economics 2018: 259-74. [CrossRef]

Chaivisuttangkun, Sirithida, and Pornsit Jiraporn. 2021. The effect of co-opted directors on firm risk during a stressful time: Evidence from the financial crisis. Finance Research Letters 39: 101538. [CrossRef]

Galindo-Martín, Miguel-Ángel, Maria-Soledad Castaño-Martínez, and Maria-Teresa Méndez-Picazo. 2021. Effects of the pandemic crisis on entrepreneurship and sustainable development. Journal of Business Research 137: 345-53. [CrossRef]

Harjoto, Maretno, and Indrarini Laksmana. 2018. The impact of corporate social responsibility on risk taking and firm value. Journal of Business Ethics 151: 353-73. [CrossRef]

Havlinova, Aneta, and Jiri Kukacka. 2021. Corporate Social Responsibility and Stock Prices after the Financial Crisis: The Role of Strategic CSR Activities. Journal of Business Ethics. [CrossRef]

He, Jie, Alastair Morrison, and Hao Zhang. 2021. Being sustainable: The three-way interactive effects of CSR, green human resource management, and responsible leadership on employee green behavior and task performance. Corporate Social Responsibility and Environmental Management 28: 1043-54. [CrossRef]

Hu, Grace Xing. 2020. Rollover risk and credit spreads in the financial crisis of 2008. Journal of Finance and Data Science 6: 1-15. [CrossRef]

International Monetary Fund. 2021. World Economic Outlook Database: October 2021. Available online: https://www.imf.org/en/ Publications/WEO/weo-database/2021/October (accessed on 24 November 2021).

Jiang, Jiaqi, and Yun Feng. 2021. The interaction of risk management tools: Financial hedging, corporate diversification and liquidity. International Journal of Finance and Economics 26: 2396-413. [CrossRef]

Kabonga, Itai. 2020. Reflections on the 'Zimbabwean crisis 2000-2008' and the survival strategies: The sustainable livelihoods framework (SLF) analysis. Africa Review 12: 192-212. [CrossRef]

Khan, Asif, Chih-Cheng Chen, Kwanrat Suanpong, Athapol Ruangkanjanases, Santhaya Kittikowit, and Shih-Chih Chen. 2021. The impact of CSR on sustainable innovation ambidexterity: The mediating role of sustainable supply chain management and second-order social capital. Sustainability 13: 12160. [CrossRef]

Kharlanov, Alexey, Yuliya Bazhdanova, Teimuraz Kemkhashvili, and Natalia Sapozhnikova. 2022. The Case Experience of Integrating the SDGs into Corporate Strategies for Financial Risk Management Based on Social Responsibility (with the Example of Russian TNCs). Risks 10: 12. [CrossRef]

Kruger, Chamay, Willem Daniel Schutte, and Tanja Verster. 2021. Using model performance to assess the representativeness of data for model development and calibration in financial institutions. Risks 9: 204. [CrossRef]

Liang, Quanxi, Jiangshan Liao, and Leng Ling. 2022. Social interactions and mutual fund portfolios: The role of alumni networks in China. China Finance Review International. [CrossRef]

Lippi, Andrea, and Simone Rossi. 2020. Run for the hills: Italian investors' risk appetite before and during the financial crisis. International Journal of Bank Marketing 38: 1195-213. [CrossRef]

Liu, Yipeng, and Fabian Jintae Froese. 2020. Crisis management, global challenges, and sustainable development from an Asian perspective. Asian Business and Management 19: 271-76. [CrossRef]

Lopata, Ewelina, and Krzystof Rogatka. 2021. CSR\&COVID19-How do they work together? Perceptions of Corporate Social Responsibility transformation during a pandemic crisis. Towards smart development. Bulletin of Geography. Socio-Economic Series 53: 87-103. [CrossRef]

Ma, Yu-Luen, and Yayuan Ren. 2021. Insurer risk and performance before, during, and after the 2008 financial crisis: The role of monitoring institutional ownership. Journal of Risk and Insurance 88: 351-80. [CrossRef]

Machokoto, Michael, Geofry Areneke, and Davis Nyangara. 2021. Financial conservatism, firm value and international business risk: Evidence from emerging economies around the global financial crisis. International Journal of Finance and Economics 26: 4590-608. [CrossRef] 
Magrizos, Solon, Eleni Apospori, Marylyn Carrigan, and Rosalind Jones. 2021. Is CSR the panacea for SMEs? A study of socially responsible SMEs during economic crisis. European Management Journal 39: 291-303. [CrossRef]

Mori, Masaki, Seow Eng Ong, and Joseph Ooi. 2022. The Revival of Business Groups' Risk Sharing: Evidence from Japanese Real Estate Investment Trust Market. Journal of Real Estate Finance and Economics 1-35. [CrossRef]

Pérez, Óscar Iván, Maria Claudia Romero, and Paola González Vargas. 2020. Interlinkages and synergies between sdg: An analysis from the perspective of social responsibility in Colombia. Desarrollo y Sociedad 2020: 191-244. [CrossRef]

Popkova, Elena G., and Bruno S. Sergi. 2021. Dataset Modelling of the Financial Risk Management of Social Entrepreneurship in Emerging Economies. Risks 9: 211. [CrossRef]

Rouleau, Linda, Markus Hällgren, and Mark de Rond. 2021. Covid-19 and Our Understanding of Risk, Emergencies, and Crises. Journal of Management Studies 58: 243-46. [CrossRef]

Safta, Ioana Lavinia, Andrada-Ioanna Sabău (Popa), and Neli Muntean. 2021. Bibliometric analysis of the literature on measuring techniques for manipulating financial statements. Risks 9: 123. [CrossRef]

Saha, Mallika, and Kumar Debasis Dutta. 2022. Does governance quality matter in the nexus of inclusive finance and stability? China Finance Review International. [CrossRef]

Servaes, Henri, and Ane Tamayo. 2013. The impact of corporate social responsibility on firm value: The role of customer awareness. Management Science 59: 1045-61. [CrossRef]

Shahzad, Akmal, Bushra Zulfiqar, Mumtaz Ali, Ayaz ul Haq, Maryam Sajjad, and Ahmad Raza. 2022. Mediating role of formalization of RM methods among the perceived business risk and organization performance. Cogent Business and Management 9: 2024116. [CrossRef]

Shayan, Niloufar Fallah, Nasrin Mohabbati-Kalejahi, Sepideh Alavi, and Mohammad Ali Zahed. 2022. Sustainable Development Goals (SDGs) as a Framework for Corporate Social Responsibility (CSR). Sustainability 14: 1222. [CrossRef]

Sinha, Avik, Sheklar Mishra, Arshian Sharif, and Larisa Yarovaya. 2021. Does green financing help to improve environmental \& social responsibility? Designing SDG framework through advanced quantile modelling. Journal of Environmental Management 292: 112751. [CrossRef] [PubMed]

Singh, Nitya. 2022. Developing Business Risk Resilience through Risk Management Infrastructure: The Moderating Role of Big Data Analytics. Information Systems Management 39: 34-52. [CrossRef]

Sinkovics, Noemi, Rudolf Sinkovics, and Jason Archie-Acheampong. 2021. The business responsibility matrix: A diagnostic tool to aid the design of better interventions for achieving the SDGs. Multinational Business Review 29: 1-20. [CrossRef]

Torrès, Olivier, Alexandre Benzari, Christian Fisch, Jinia Mukerjee, Abdelaziz Swalhi, and Roy Thurik. 2021. Risk of burnout in French entrepreneurs during the COVID-19 crisis. Small Business Economics 2021: 1-23. [CrossRef]

UNDP. 2022. SDG Index and Dashboards 2018-2020. Available online: https://www.sdgindex.org/reports/sdg-index-anddashboards-2018/ (accessed on 3 February 2022).

Vagin, Sergei, Elena Kostyukova, Natalia Spiridonova, and Tatiana Vorozheykina. 2022. Financial Risk Management Based on Corporate Social Responsibility in the Interests of Sustainable Development. Risks 10: 35. [CrossRef]

Waheed, Abdul, and Qingyu Zhang. 2022. Effect of CSR and Ethical Practices on Sustainable Competitive Performance: A Case of Emerging Markets from Stakeholder Theory Perspective. Journal of Business Ethics 175: 837-55. [CrossRef]

Weber, Véronique, and Anke Müßig. 2022. The Effect of Business Strategy on Risk Disclosure. Accounting in Europe 1-36. [CrossRef]

Wentzel, Lance, Jullius Auodeji Fapohunda, and Rainer Haldenwang. 2022. The Relationship between the Integration of CSR and Sustainable Business Performance: Perceptions of SMEs in the South African Construction Industry. Sustainability 14: 1049. [CrossRef]

World Bank. 2021. Indicators: Financial Sector. Available online: https:/ / data.worldbank.org/indicator (accessed on 24 November 2021).

Yankovskaya, Veronika, Vladimir Osipov, Aleksei Zeldner, Tatiana Panova, and Vitalii Mishchenko. 2021. Institutional matrix of social management in region's economy: Stability and sustainability vs innovations and digitalization. International Journal of Sociology and Social Policy 41: 178-91. [CrossRef]

Zhang, Yuming, Chao Xing, Quanli Zhang, and Xinyue Zhang. 2022. Crises and changes: The impacts of CSR expenditure on loan and subsidy allocation in China's Pre- and Post-Pandemic periods. Finance Research Letters 102697. [CrossRef]

Zizi, Youssef, Amine Jamali-Alaoui, Badreddine El Goumi, Mohamed Oudgou, and Abdelsalam El Moudden. 2021. An optimal model of financial distress prediction: A comparative study between neural networks and logistic regression. Risks 9: 200. [CrossRef] 